\title{
Analysis on the Method of Ideological and Political Education in Higher Vocational English Curriculum in the Network Information Age
}

\author{
Huang Meirong \\ Yangling Vocational and technical College, Shaanxi, 712100, China
}

\begin{abstract}
With the change of times, the position of ideological and political education in higher vocational teaching has also changed. At the National ideological and political work Conference, General Secretary Xi Jinping proposed that every process of education and teaching should be ideological and political.Under the guidance of curriculum ideological and political thought, English teachers in higher vocational colleges should seriously think and carry out ideological and political education in English teaching, so as to achieve the purpose of curriculum ideological and political education through English teaching.
\end{abstract}

Keywords: Internet Information Age; Higher Vocational English: Ideological and Political Education; Method Analysis

The ideological consciousness of higher vocational students in the era of network information has extremely unstable characteristics with the infiltration of diversified culture, so the ideological and political education of higher vocational students is the basis of realizing the teaching goal of talent training in higher vocational colleges.Curriculum ideological and political teaching is to integrate ideological and political teaching into each course teaching, so that ideological and political work can be embodied in every link, every aspect and everyone in higher vocational teaching, so that students can realize ideological and political education in every professional course, and let correct ideological and political views run through the whole stage of higher vocational study, so that students can form ideological and moral quality with socialist characteristics. As a public basic course in higher vocational

https://doi.org/10.47852/bonviewCETR2020010209

This is an open access article published by the BON VIEW PUBLISHING PTE. under the Creative Commons Attributions License. 
teaching, English students are required to carry out English students in each major. Therefore, the construction of ideological and political education system in higher vocational English teaching is an important part of higher vocational ideological and political education.

\section{Excavate the material of socialist core values in English teaching materials for ideological and political education}

English teaching materials include a lot of ideological and political education materials in the design. In English teaching, English teachers in higher vocational colleges must dig deeply into the materials of ideological and political education on the basis of English knowledge teaching. Let higher vocational students cultivate socialist core values in English learning. Through the combination of English teaching and ideological and political education in higher vocational education, students in higher vocational education carry on the correct ideological, moral and value system construction in the course of English teaching ${ }^{[1]}$.

For example, the beginning of English teaching materials in higher vocational colleges is the application of English daily knowledge to the report of higher vocational students entering the school, the communication and getting along with new roommates, and how to integrate into the campus life of higher vocational colleges.During the Warming up part of this chapter, English teachers in higher vocational colleges can make students discuss freely, talk about their consideration when choosing their major, their yearning and expectation for the coming life in higher vocational colleges, their vision of the future career, etc.During the Listening and Speaking of this part of the Listening and Speaking, English teachers in higher vocational colleges enable higher vocational students to master vocabulary related to campus through listening teaching, and guide students to express their ideas about the new higher vocational life in English simply and correctly.English teachers teach vocabulary and language in this part of Reading and Vocabulary teaching about all aspects of campus life of higher vocational students.In this part of teaching, senior English teachers should infiltrate the elements of ideological and political education on the basis of English knowledge teaching, so as to carry out ideological and political education teaching for students.For example, when it comes to the life of dormitory English vocabulary and language, English teachers should guide students to deal with the relationship between roommates correctly, cultivate students' awareness of roommates as family members, Guide students to use tolerance and understanding of family to get along with roommates, let students create a harmonious atmosphere in dormitory, so as to cultivate students' ability to get along with others. When it comes to vocabulary and language about extracurricular activities, English teachers can guide students to meaningful social practices, such as volunteer service, resistance to illegal religious activities, and so on. Through the study of English language in daily life, connecting English teaching with students' life not only stimulates students' interest in learning English, but also integrates ideological and political education into it. Let students learn English knowledge and accept ideological and political education at the same time ${ }^{[2]}$. 


\section{Combining students' major with English learning to cultivate students' professional spirit in English teaching}

The teaching goal of higher vocational education is to train high-quality skilled talents for the country and society, so higher vocational students must have high quality, that is, good professional spirit and professional accomplishment. In higher vocational English teaching, we should combine the students' professional characteristics, analyze the students' professional accomplishment and professional spirit, dig the material in the English teaching material, integrate the professional accomplishment and professional spirit into the English knowledge teaching, and let the students have a deep understanding of the professional accomplishment and professional spirit in the process of English learning ${ }^{[3]}$.

For example, in Unit 8 of the New Vocational English Audio-Visual speaking Unit 1," Career" teaching, English teachers should let students master the vocabulary of job interviews and career planning in teaching, and ask students to express their self-introduction and interview questions in English.The teaching purpose of this course is to guide the career planning of higher vocational students, to promote the establishment of students' correct outlook on career selection, and to integrate students' oral English learning with their future careers. In English teaching, students not only master relevant English knowledge, but also cultivate students' professional accomplishment and professionalism.English teachers in higher vocational colleges can arrange tasks for students in the first step: choose the most ideal occupation according to their own actual situation for career planning, if there are no words or expressions can be used to consult the teacher, ask other students, self-inquiry etc. The second step is to let the students have a group discussion:Divide the students into groups, let the group members discuss each other, share their career plans in the group, and guide the students to discuss what preparations can be made for their future career in the higher vocational study stage. What professional qualities to be cultivated and what professional spirit is needed.The third step is to summarize the results of the discussion and consolidate the English knowledge. Through this process, English teachers not only put in place English knowledge about personal resume, interview skills and career planning, but also cultivate students' professional accomplishment and professionalism through curriculum thinking.

\section{English teachers should train students to set up correct three views}

Although higher vocational students have initially established their own outlook on life, world outlook and values, but with the infiltration of multiculturalism, the ideological cognition of high school students will change with the change of various factors.In the course of English teaching in higher vocational colleges, English teachers should always pay attention to the students' ideological trends, guide the students' ideas in time, prevent the students' ideological deviation, and thus guide the students to establish a correct outlook on life, world outlook and values ${ }^{[4]}$. 
For example, the third unit of higher vocational English teaching material is to teach English vocabulary and language involved in higher vocational students' consumption. In addition to the teaching of basic English knowledge, higher vocational English teachers should guide students' consumption habits, expenditure reduction, rational consumption and budget planning.English teachers in Listening and Speaking part of the teaching should ask students to have a simple dialogue on consumption, grasp the dialogue on consumption in the textbook, and guide students to discuss their consumption habits in class. Let students analyze what is unreasonable consumption, how to reduce and control their consumption, how to cultivate their good consumption habits.Reading and Vocabulary this part of the teaching, English teachers should ask students to master the English vocabulary and language of budget expenditure, and understand how to carry out budget expenditure according to the text. English teachers let students make budget plans in class according to their actual consumption, and analyze and discuss the impact of unreasonable consumptionIn this part of teaching, English teachers should not only ask students to understand and grasp the English vocabulary and language about consumption, but also guide students to establish a correct view of consumption, plan their own consumption reasonably, make budget plans suitable for themselves, and cultivate their own good consumption habits, so as to guide students to carry out rational consumption and establish a correct view of consumption.

\section{Strengthen the theoretical level and teaching ability of English teachers' ideological and political education}

The theoretical level and teaching quality of vocational English teachers' ideological and political education are directly related to the promotion and quality of English curriculum.Ideals and beliefs are the primary assessment conditions for higher vocational English teachers to become "four you" teachers. Therefore, under the background of network information age, English teachers in higher vocational colleges should have excellent theoretical knowledge of English majors and teaching and scientific research ability. Also have excellent socialist core values and moral literacy.If higher vocational English teachers want to carry out ideological and political education in English teaching, they must improve their ideological and political theory first. Only when they have fully grasped and understood the ideological and political theory can they integrate ideological and political education with English daily teaching and promote the development of curriculum ideological and political education in English teaching; In order to improve the teaching ability of ideological and political education, English teachers in higher vocational colleges can deeply understand the positive effect of socialist core values on their growth and development in English teaching. Only in this way can students actively participate in the ideological and political education activities in English teaching ${ }^{[5]}$. English mainly shows western culture. English teachers should guide students to face the impact of western culture on their own ideology correctly in teaching, adhere to Marxism-Leninism, Mao Zedong thought, Deng Xiaoping theory, three represents as the guiding ideology, strengthen the ideals and 
beliefs of socialism and communism, and adhere to the socialist road.In addition to the model articles in the teaching materials, English teachers should quote more stories of their own country and guide students to discover the positive image of the country when carrying out ideological and political education for students. English teachers in higher vocational colleges should cultivate their excellent character, such as loving their work, respecting and caring for their students and building up their moral character. On the basis of teaching, they should pay the same attention to educating people, teach students by words and deeds, so that students can feel the noble character of English teachers and infect students over the years. Guide students to move in the right direction ${ }^{[6]}$.

\section{Conclusion}

In the age of network information, the ideological consciousness of higher vocational students is impacted by multi-culture. It is also important for higher vocational students who have established their outlook on life, world outlook and values to learn basic cultural knowledge and receive ideological and political education. In view of the shortage of courses in ideological and political courses in higher vocational colleges, this paper puts forward the idea of transforming ideological and political courses into courses of ideological and political teaching. As the most extensive and long-term subjects in higher vocational colleges, English has become the main way to carry out courses of ideological and political education in English teaching And the education of students fully combined.

\section{References}

[1] Wang Wenjing. Discussion on Ideological and Political Concept and Practice of English Course in Higher Vocational College in J]. Information Age Education Modernization ,2020, v.7(5):155-156.

[2] Cheng Xiaohong. Analysis on the Significance and Realization Approach of Ideological and Political J]. in English Curriculum of Higher Vocational College Channel Science ,2019,(6):64-67.

[3] Li Hua, Li Hongyan. Exploration and Practice of Ideological and Political Education Teaching in Higher Vocational Public English Curriculum Based on Cloud Classroom [J]. English Plaza ,2020, No.122(14):90-93.

[4] $\mathrm{Lu}$ Xiaohua. Exploration and Practice on the Implementation Path of English Teaching in Higher Vocational College under the Background of "Ideological and Political J]. of Curriculum "[ Journal of Hubei Open Vocational College.

[5] Jin Lei. A Study on the Effective Path of Integrating Ideological and Political Elements into Higher Vocational English Teaching in J]. New Era Northern Lights ,2019,(9):174-175.

[6] Liu Xiaoling, Wei Hong, Gong Xiangwei. A Preliminary Study on Ideological and Political Studies in English Teaching Courses J]. Higher Vocational Education Textile and clothing Education ,2019(3):227-230. 